Journal of Advanced Research in Fluid Mechanics and Thermal Sciences

Journal homepage: www.akademiabaru.com/arfmts.html ISSN: 2289-7879

\title{
Thermal Inactivation of Talaromyces flavus Ascospores in Pineapple Juice as Influenced by Temperature, Soluble Solids, and Spore Age
}

\author{
Evelyn $^{1,}{ }^{*}$, Sri Rezeki Muria ${ }^{1}$, Chairul $^{1}$, Doni Fozla ${ }^{1}$, Fryda Kusumawati Khoirunnisa $^{1}$ \\ Department Chemical Engineering, Faculty of Engineering, Universitas Riau, Pekanbaru, 28293, Indonesia
}

\section{ARTICLE INFO}

\section{Article history:}

Received 20 December 2019

Received in revised form 17 March 2020

Accepted 19 March 2020

Available online 18 April 2020

\section{ABSTRACT}

The ascospores of Talaromyces species can survive pasteurization and grow in high acid fruit juices. In this study, the thermal inactivation of Talaromyces flavus ascospores in pineapple juice was carried out and the log reductions were counted. First, the effect of temperature $\left(\mathrm{T}: 80-90^{\circ} \mathrm{C}\right)$, soluble solid content (SS: $10-30^{\circ} \mathrm{Brix}$ ), and spore age (3060 days) on the viability of ascospores were investigated. Then, the first-order kinetic parameters ( $D$ and z-values) were determined from the log survivor curves. Results of the thermal processes showed that higher log reductions for higher temperatures (5.2 $\log$ for $90^{\circ} \mathrm{C}$ vs. $0.89 \log$ for $85^{\circ} \mathrm{C}$ and $0.28 \log$ for $80^{\circ} \mathrm{C}$ ) were obtained at $10^{\circ} \mathrm{Brix}$ after $15 \mathrm{~min}$ heat treatments. Lower spore reductions were observed at higher SS (1.5 log for $30^{\circ}$ Brix vs. $2.4 \log$ for $20^{\circ}$ Brix and $3.0 \log$ for $12^{\circ}$ Brix after 9 min at $90^{\circ} \mathrm{C}$ ). Longer time needed to inactivate the older spores (53.8 $\mathrm{min}$ for 30 day-old-spores vs. $67.1 \mathrm{~min}$ for 60 day-old-spores). The log survivors are better described by the first-order kinetics at $80-90^{\circ} \mathrm{C}$. The estimated $\mathrm{D}$-values in $12^{\circ} \mathrm{Brix}$ juice were $63.8 \mathrm{~min}, 16.9 \mathrm{~min}$ and 2.89 min for 80,85 and $90^{\circ} \mathrm{C}$, respectively, with z-value of $7.9^{\circ} \mathrm{C}$. This result emphasizes the importance of temperature, SS, and ascospore age on the heat resistance of $T$. flavus ascospores in high acid fruit juice.

Keywords:

Thermal processing; mold spores;

survival; kinetic; modelling

Copyright $\odot 2020$ PENERBIT AKADEMIA BARU - All rights reserved

\section{Introduction}

Talaromyces is a mold that is widely distributed in soil. For example, Talaromyces flavus has been isolated in 16 countries around the world [1]. Talaromyces species is a great concern in fruit products since the ascospores can be very resistant to heat. In favorable conditions (storage temperature and food characteristics such as $\mathrm{pH}$, water activity, food constituents) after pasteurization, the ascospores can germinate and grow in fruit products to attain high numbers e.g. $10^{5}-10^{6} / \mathrm{g}$ or $\mathrm{mL}$ and cause spoilage or food-borne diseases. Decimal reduction values (D-values) at $91^{\circ} \mathrm{C}$ between $0.9 \mathrm{~min}$ in strawberry pulp and $2.9 \mathrm{~min}$ in grape juice have been reported for this species [2, 3]. Few

\footnotetext{
* Corresponding author.

E-mail address: evelyn@eng.unri.ac.id (Evelyn)
}

https://doi.org/10.37934/arfmts.69.2.111119 
Talaromyces sp. such as Talaromyces macrosporus and Talaromyces wortmannii are known as mycotoxin producers [4].

Indonesia is rich in the production of tropical fruits, placing the country in the top twenty for world fruits producers. According to Indonesian Central Bureau of Statistics in 2015 [5], Indonesia produced 18.4 million tons of fruits with the major commodities are banana, mango, orange, pineapple and durian. Pineapple is in the fourth place with 1.7 million tons, which some of the products are coming from Riau Province. Brazil, Thailand, Philippines, China are also main pineapple producers in the world, contributing to $52 \%$ of the total outputs [6]. The abundant production of these fruits should be followed with a proper preservation method to avoid significant economic losses and to maintain food safety as well as sensorial and nutritional quality. Contamination and isolation of $T$. flavus in pineapple juice have been reported by King and Halbrook [7].

Despite development of many non-thermal pathogen and spoilage inactivation technologies in recent decades [8-10] and high energy consumption drawback of thermal processing [11], heat treatment is still the most widely applied technology in the food industries. Traditional heat treatment using hot-filling process applies 92 and $105^{\circ} \mathrm{C}$ for $15-30$ s to process the foods [12]. However, these conditions were not specifically reported for pineapple juice. Due to the importance of $T$. flavus in pineapple juice, therefore the objectives of this study were: (i) to investigate the effect of temperature on the log reductions of $T$. flavus spores after thermal inactivation, (ii) to investigate the effect of soluble solids (SS) on the log reductions of T. flavus spores after thermal inactivation; (ii) to investigate the effect of ascospore age on the log reductions of $T$. flavus spores after thermal inactivation, and; (iv) to model the inactivation of these spores after thermal treatments.

\section{Methodology}

2.1 Mold

Talaromyces sp. InaCC F155 was obtained from Indonesian Culture Collection (InaCC), Research Center for Biology, Indonesian Institute of Sciences or LIPI. The species was isolated from soil at Mt. Bromo, Ngadisari, Pasuruan Regency, Indonesia and identified as Talaromyces flavus.

\subsection{Ascospore Production}

Ascospores of $T$. flavus were obtained after growth for four weeks at $30^{\circ} \mathrm{C}$ on potato dextrose agar (PDA) [13]. The spores were collected by flooding the surface of the culture plates with $5 \mathrm{~mL}$ sterile distilled water (SDW) and gently rubbing from the agar surface with a sterile bent glass rod. The spore suspension was subsequently filtered through layers of gauze to remove any remaining hyphal fragments. Spore pellets were obtained after centrifugation in sterile SDW at 4,000 $\mathrm{xg}, 15 \mathrm{~min}$, $4^{\circ} \mathrm{C}$, and the procedure was repeated three times. The final spore suspension was then stored at $2^{\circ} \mathrm{C}$ in SDW.

\subsection{Pineapple Juice Preparation and Inoculation}

Pineapples from local market in Riau Province were cut into small pieces and blended in a sterile laboratory scale blender. The juice $\left(12^{\circ} \mathrm{Brix}, \mathrm{pH} 4.3\right)$ was used as the medium to suspend the $T$. flavus ascospores and adjusted to 20 or $30^{\circ}$ Brix with sucrose, depending on thermal experiments. Aliquots (ca. $1.0 \mathrm{~mL}$ ) of $T$. flavus spore solution were inoculated into $2.0 \mathrm{~mL}$ of pineapple juice to yield an initial spore concentration of approximately $10^{6} \mathrm{cfu} / \mathrm{mL}$ of juice. 


\subsection{Spore Enumeration}

The mold ascospore concentration in pineapple juice before and after processing was determined by spread plating onto PDA [14]. For the initial spore concentration, the number was determined after a heat shock $\left(75^{\circ} \mathrm{C}, 5 \mathrm{~min}\right)$ of spores in pineapple juice in a thermostatic water bath [15]. Prior to plating, $1 \mathrm{~mL}$ spore samples were decimal diluted using $9 \mathrm{~mL}$ saline solution (0.85\%). Each tube dilution was mixed repeatedly using a high-speed vortex mixer to yield a uniform spore suspension and plated twice. The plates were then incubated at $30^{\circ} \mathrm{C}$ for 3 to 5 days until visible colonies were formed. Plates with 20 to 100 colonies were used for enumeration, and average colony counts were calculated. Ascospore concentration was expressed in $\mathrm{cfu} / \mathrm{mL}$ of juice sample.

\subsection{Thermal Processing}

Thermal resistance of $T$. flavus ascopores was carried out at three temperatures: 80,85 and $90^{\circ} \mathrm{C}$, according to previous method applied for heat-resistant ascopores [16]. Initially, thermostatic water bath was heated until the treatment temperature was reached $\left( \pm 1^{\circ} \mathrm{C}\right)$. The inoculated pineapple juice samples contained in thermal death tubes were then submerged into the preheated thermostatic water bath, and heated for various times. Treated samples were taken out at different time intervals and kept in an ice water bath until microbial enumeration.

\subsection{Data Model Fitting and Statistical Data Analysis}

For each spore age or temperature, two survival experiments were carried out for thermal treatments. For each survival experiment, duplicate samples were processed each time. Then, the average data of log $\mathrm{N} /$ No versus time were plotted in a chart, in which a log-linear relation was observed. No is the initial or untreated ascospore population $(\mathrm{cfu} / \mathrm{mL}), \mathrm{N}$ is the number of ascospores after being exposed to a lethal (heat) treatment for a specific time ( $t$ ). Thus, first-order kinetics was used to model the thermal inactivation results in order to compare with literature results. In this model, decimal reduction times $\left(D_{T}\right.$-values, the time in min at a certain temperature necessary to reduce microbial population by $90 \%$ ) were calculated from the reciprocal of the slope in Eq. (1) [17]. The temperature coefficient, $\mathrm{z}_{\mathrm{T}}$-value $\left({ }^{\circ} \mathrm{C}\right)$ is the temperature increase that results in a 10 -fold decrease in the $\mathrm{D}_{T}$-value and was estimated from the negative reciprocal of the slope as in Eq. (2). $D_{\text {Tref }}$ is $D$-value at the reference temperature $T_{\text {ref }}$ (can be any reference temperature, ${ }^{\circ} \mathrm{C}$ ), $\mathrm{T}$ is the temperature of the isothermal treatment $\left({ }^{\circ} \mathrm{C}\right)$. A t-test (Statistica 8.0, Statsoft Inc., USA) was used to compare the log reductions of mold spores at different temperature/soluble solids/spore age, after a specific processing time.

$$
\begin{aligned}
& \log \frac{N}{N_{0}}=-\frac{t}{D_{t}} \\
& \log \frac{D_{T}}{D_{\text {Tref }}}=\frac{T_{r e f}-T}{z_{T}}
\end{aligned}
$$




\section{Results}

\subsection{Effect of Temperature on The Log Reductions of T. Flavus Ascospores}

Figure 1 shows the log survivors of $T$. flavus ascospores in pineapple juice $\left(12^{\circ} \mathrm{Brix}\right)$ after thermal processes at $80-90^{\circ} \mathrm{C}$. As expected, the higher the temperature the higher the log reductions obtained, indicating the important role of temperature for inactivating the ascospores. For example, increasing the temperature from $80^{\circ} \mathrm{C}$ to $90^{\circ} \mathrm{C}$ at $12^{\circ} \mathrm{Brix}$ for $15 \mathrm{~min}$ increased the $T$. flavus spore inactivation by almost $5 \log (p<0.05)$. Quintavalla and Spotti [3] obtained 4.6 log increase for thermal inactivation of $T$. flavus CBS 317.63 in grape juice after increasing the temperature from $88^{\circ} \mathrm{C}$ to $90^{\circ} \mathrm{C}$ for $15 \mathrm{~min}$ (estimated from the $\mathrm{D}_{\mathrm{T}}$-values). Likewise, Scott and Bernard [18] obtained 4.8 log increase for thermal inactivation of $T$. flavus 83-41 in apple juice after increasing the temperature from $87.8^{\circ} \mathrm{C}$ to $90.6^{\circ} \mathrm{C}$ for $15 \mathrm{~min}$. Aragão [2] achieved much higher log reduction (12 log) of $T$. flavus also in apple juice when the temperature was changed from $85^{\circ} \mathrm{C}$ to $90^{\circ} \mathrm{C}$. Decreasing of the heat resistance of several strains Talaromyces $s p$. with increasing temperature were also observed in other medium i.e. $16^{\circ}$ Brix glucose-tartrate heating medium [8]. It has been known that mechanism inactivation of spores by heat is due to dipicolinic acid (DPA) release leading to spore core hydration, followed by protein denaturation of the more hydrated spore core [19]. Variations in T. flavus ascospore reductions after thermal treatments in the literature might be due to many factors, for example different spore preparations [8], type and temperature of growth medium [20], as well as age and sugar content in the inactivation medium [21].

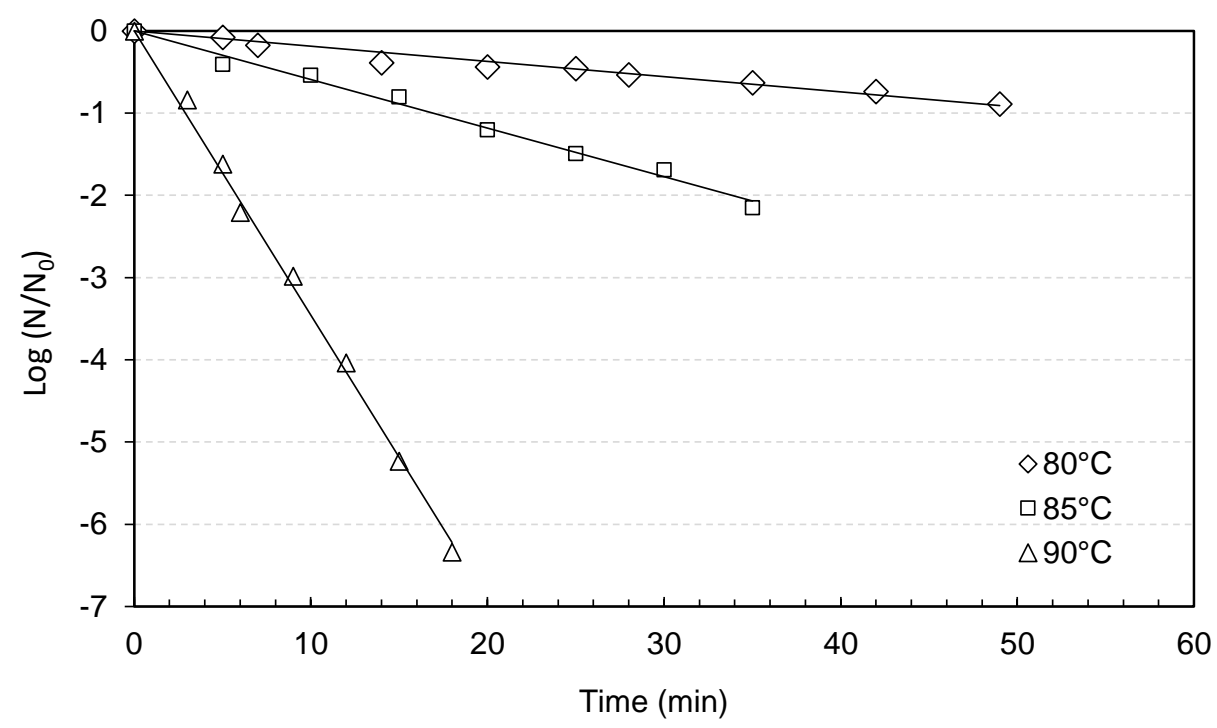

Fig. 1. Effect of temperature on the thermal inactivation Talaromyces flavus ascospores in pineapple juice $\left(12^{\circ} \mathrm{Brix}\right)$

\subsection{Effect of Soluble Solid Content on The Log Reductions}

The effect of soluble solid contents or SS $\left(10-30^{\circ} \mathrm{C}\right)$ on the log survivors of $T$. flavus ascospores in pineapple juice after thermal processes at $90^{\circ} \mathrm{C}$ is illustrated in Figure 2. A decrease in the number of inactivated ascospores was observed with increasing percentage (\%) weight of sucrose. As can be seen from the figure, a 3-log reduction was obtained for $12^{\circ}$ Brix compared to $2.4 \log$ for $20^{\circ}$ Brix and $1.5 \log$ for $30^{\circ} \mathrm{Brix}$ pineapple juices after $9 \mathrm{~min}(\mathrm{p}<0.05)$. The typical level of microbial contamination in juice is around $10^{3} \mathrm{cfu} / \mathrm{mL}$ [22], indicating the difficulty in reducing the spores to that amount with higher SS (20 and $\left.30^{\circ} \mathrm{Brix}\right)$ content. These results are in agreement with Beuchat [20] in which lower 
log reductions were observed with higher sucrose concentration (60\% as opposed to $15 \%$ ), reducing the water activity (aw) from 0.99 to 0.96 . Silva et al., [23] also reported the protective effect of SS (5$60^{\circ} \mathrm{Brix}$ ) on the heat resistance of Alicyclobacillus acidoterrestris spores suspended in malt extract broth, whereas other authors demonstrated generally an increase in the heat resistance of Byssochlamys nivea and Neosartorya fischeri mold ascospores suspended in pineapple and papaya juices after increasing the SS from 13 to $27^{\circ}$ Brix [24]. The same phenomenon i.e. a significant increase in the D-values observed upon increasing the sucrose concentration, was also reported by other authors [25].

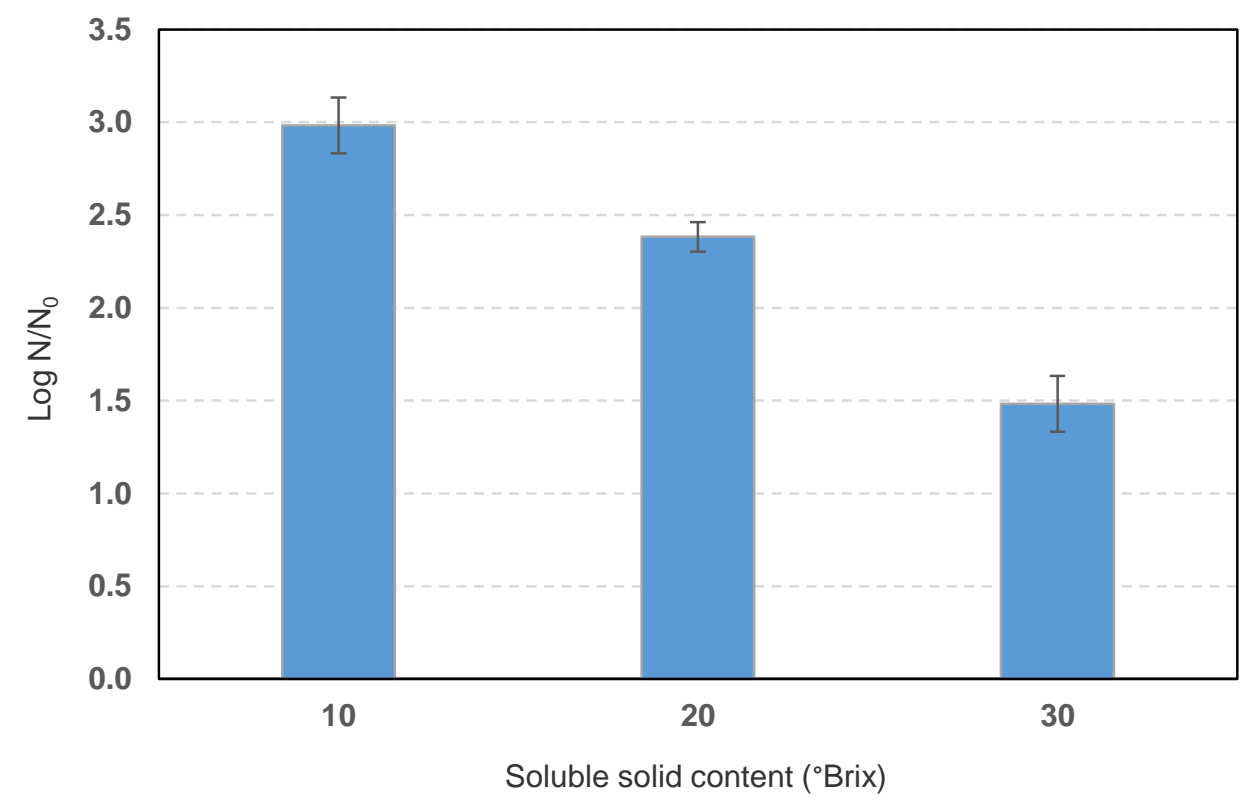

Fig. 2. Effect of soluble solid content $\left(12,20\right.$ and $\left.30^{\circ} \mathrm{Brix}\right)$ on the $90^{\circ} \mathrm{C}$-thermal inactivation Talaromyces flavus ascospores in pineapple juice

\subsection{Effect of Ascospore Age on The Log Reductions}

Figure 3 shows the effect of ascospore age from 30 to 60 days on the time required to inactivate 1-log T. flavus ascospores at 80,85 , and $90^{\circ} \mathrm{C}$. Generally, the older the spores, the longer the time needed for the inactivation at all temperatures. For $80^{\circ} \mathrm{C}$ thermal treatment, the time needed to inactivate 1-log of the ascospores were $53.8 \mathrm{~min}$ for 30 day-old-spores, $59.88 \mathrm{~min}$ for 45 day-oldspores and $67.11 \mathrm{~min}$ for 60 day-old-spores $(p<0.05)$ (Figure 3(a)). Similarly, only 2.89 min was needed to inactivate 1-log of 30 day-old-spores as opposed to $4.80 \mathrm{~min} 60$ day-old-spores at $90^{\circ} \mathrm{C}$ $(p<0.05)$ (Figure $3(c))$. Changes in the spore ultrastructure or nanostructure through formation of multilayers in the ascospore's wall can contribute to the higher resistance of older ascospores [26, 27]. Higher ratio of asci free ascospores in older spores might also become another cause for the heat resistance of older spores [28]. Higher resistance of older ascospores than younger ascospores were also observed in other studies under thermal and non-thermal inactivation methods $[28,29,30]$. 


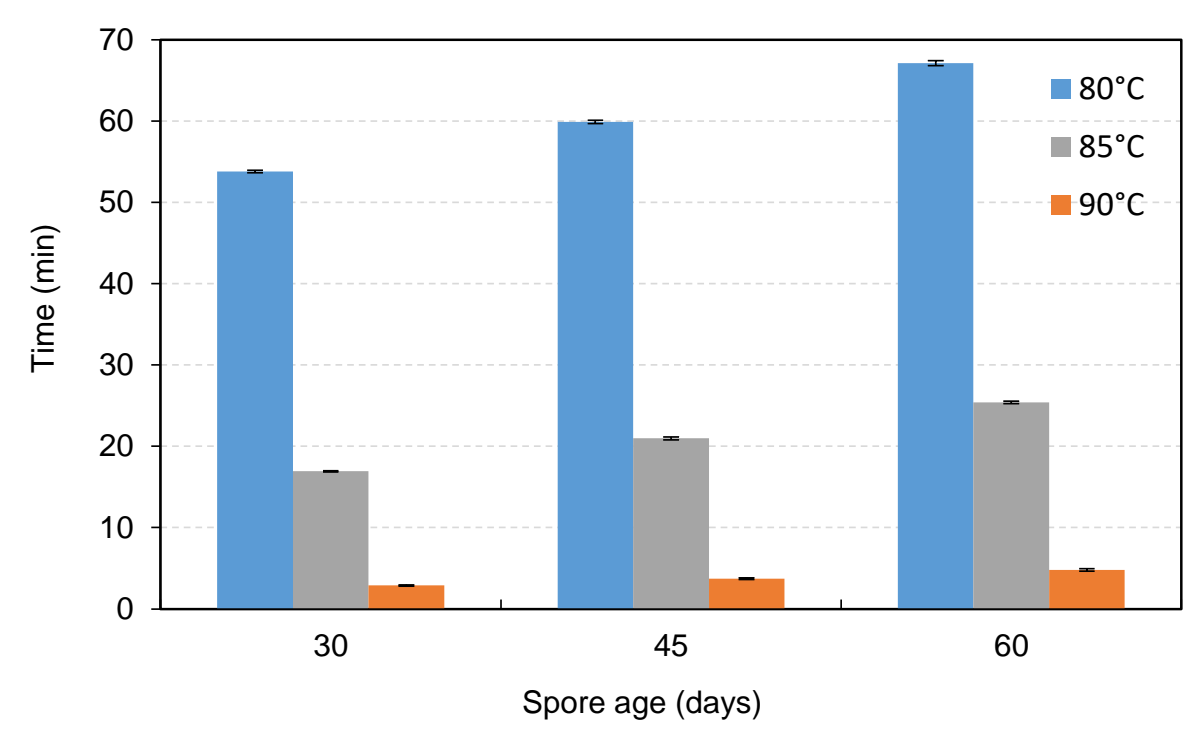

Fig. 3. Effect of ascospore age $\left(30,45\right.$ and 60 days) on the 80,85 , and $90^{\circ} \mathrm{C}$ thermal inactivation of Talaromyces flavus ascospores in pineapple juice $\left(12^{\circ}\right.$ Brix $)$

\subsection{Modelling the Thermal Inactivation of Talaromyces Flavus Ascospores In Pineapple Juice}

Based on the general appearance of the thermal survival lines in Figure 1, a linear equation was attempted to model the spore survivors, and the kinetic parameters were estimated (Table 1). In general, the first-order kinetic models are supported by the D-values temperature dependence $\left(R^{2}=0.96-0.99\right)$. Exposure to higher temperatures resulted in higher lethality of heat treatments, thus lowering the minutes required to inactivate the ascospores. At $90^{\circ} \mathrm{C}$, the D-value obtained was 2.89 min as opposed to $15.9 \mathrm{~min}$ at $85^{\circ} \mathrm{C}$ and $53.8 \mathrm{~min}$ at $80^{\circ} \mathrm{C}$. DPA release leading to damage of one or more key proteins has been a common phenomenon for spore killing by moist heat [19]. The theory suggests that more heat resulted in significant loss of DPA and protein unfolding or denaturation. Scott and Bernard [18] and Aragão [2] reported almost similar D90 ${ }^{\circ} \mathrm{c}-$ values of $T$. flavus and $T$. macrospores ascospores in apple/grape juices as reported in this study (2.77-2.89 $\mathrm{min}$ ) despite the large $D_{80^{\circ} \mathrm{C}}$-values reported ( $>265.5 \mathrm{~min}$ ), whereas Beuchat [31] reported a wide range of $\mathrm{D}_{90^{\circ} \mathrm{C}-\mathrm{values}}$ T. flavus NFPA-2 strain in bluberry/peach/strawberry puree (1.13-7.5 min). To conclude, variation in the D-values of Talaromyces $s p$. ascospores might be attributed to interaction of various influencing factors, namely composition of fruit products and strain. The z-values estimated in this study were $7.9^{\circ} \mathrm{C}$ (Table 1), which are within the expected values for most mold ascospores. 


\section{Table 1}

$D$ and $z$-values of Talaromyces flavus ascopores in fruit products

\begin{tabular}{|c|c|c|c|c|}
\hline Temperature $\left({ }^{\circ} \mathrm{C}\right)$ & Fruit products & $D_{T}$-value (min) & z-value $\left({ }^{\circ} \mathrm{C}\right)^{\mathrm{a}}$ & Reference \\
\hline 80 & Pineapple juice & 53.8 & $7.9 \pm 0.09$ & This study \\
\hline 85 & $\left(12^{\circ}\right.$ Brix $)$ & 16.9 & $R^{2}=0.96-0.99$ & \\
\hline 90 & & 2.89 & & \\
\hline 80 & Blueberry puree & 648.6 & 5.4 & [24] \\
\hline 85 & & 69.9 & & \\
\hline 90 & & 7.5 & & \\
\hline 80 & Cherry puree & 224.0 & 7.7 & \\
\hline 85 & & 25.38 & & \\
\hline 90 & & 1.13 & & \\
\hline 80 & Strawberry puree & 449.8 & 5.3 & \\
\hline 85 & & 51.9 & & \\
\hline 90 & & 5.99 & & \\
\hline 80 & Apple juice & 265.5 & 5.2 & [18] \\
\hline 85 & & 27.7 & & \\
\hline 90 & & 2.89 & & \\
\hline 80 & Grape juice & 384.6 & 4.8 & [2] \\
\hline 85 & & 32.6 & & \\
\hline 90 & & 2.77 & & \\
\hline
\end{tabular}

\section{Conclusions}

The current study demonstrates that $10^{\circ} \mathrm{C}$ increase in the temperature resulted in 5 more log reductions of Talaromyces flavus ascopores in pineapple juice after $15 \mathrm{~min}$. Soluble solid (SS) content caused a protective effect towards temperature inactivation of spores, with lower reductions occurring at higher SS. Additionally, longer inactivation was needed for older spores (2.89 min for 30 day-old-spores as opposed to $4.80 \mathrm{~min} 60$ day-old-spores at $90^{\circ} \mathrm{C}$ ). The first-order kinetics described well the thermal inactivation of $T$. flavus ascopores. The heat resistance analysis of $T$. flavus ascopores might provide further information for pasteurization processes required for pineapple juice.

\section{Acknowledgement}

We would like to express our deep gratitude to Directorate General of Research, Technology, and Higher Education Republic Indonesia through Penelitian Dasar Unggulan Perguruan Tinggi (PDUPT) Project Number 760/UN19.5.1.3/PT.01.03/2019. The support from laboratory and administrative staffs from the Chemical Engineering Department and Faculty of Mathematics and Science, University of Riau Indonesia, is appreciated.

\section{References}

[1] Fravel, D. R., and P. B. Adams. "Estimation of United States and world distribution of Talaromyces flavus." Mycologia 78, no. 4 (1986): 684-686. https://doi.org/10.1080/00275514.1986.12025308

[2] Aragão, Glaucia Maria Falcão de. "Identificação e determinação da resistência térmica de fungos filamentosos termo-resistentes isolados de polpa de morango." (1989).

[3] Quintavalla, Stefania, and Elisabetta Spotti. "Heat resistance of Talaromyces flavus, Neosartorya fischeri and Byssochlamys nivea isolated from fresh fruits." MAN Microbiologie, aliments, nutrition 11, no. 3 (1993): $335-341$.

[4] Frisvad, J.C, R.A. Samson, and A.C. Stolk. "Chemotaxonomy of Eupenicillium javanicum and Related Species Plenum Press." New York (1990). https://doi.org/10.1007/978-1-4899-3579-3 39 
[5] Central Bureau of Statistics. "Produksi Tanaman Buah-Buahan Badan Pusat Statistik." Jakarta (2015).

[6] Coveca, C. A. "Comision veracruzana de comercializacion agropecuaria." Gobierno del Estado de Veracruz, México [in Spanish] (2002).

[7] DOUGLAS KING JR, A., and W. U. Halbrook. "Ascospore heat resistance and control measures for Talaromyces flaws isolated from fruit juice concentrate." Journal of food science 52, no. 5 (1987): 1252-1254. https://doi.org/10.1111/i.1365-2621.1987.tb14055.x

[8] Evelyn, Filipa. "Inactivation of Pathogenic Microorganisms in Foods by High Pressure Processing." In Food Safety and Protection, pp. 341-377. CRC Press, 2017.

https://doi.org/10.1201/9781315153414-10

[9] Evelyn, and Silva Filipa Vinagre Marques da. "Heat assisted HPP for the Inactivation of bacteria, moulds and yeasts spores in foods: log reductions and mathematical models." Trends in Food Science and Technology, no. 88 (2019): 143-156. https://doi.org/10.1016/j.tifs.2019.03.016

[10] Silva, F. V. M. "Perspectives of high power ultrasound in food preservation." In IOP Conference Series: Materials Science and Engineering, vol. 345, no. 1, p. 012046. IOP Publishing, 2018.

https://doi.org/10.1088/1757-899X/345/1/012046

[11] Peesel, R.H., M. Philippa, G. Schumma, J. Hesselbacha, and T.G. Walmsley. "Energy efficiency measures for batch retort sterilization in the food processing industry." Chemical Engineering Transactions, no. 52 (2016): 163-168.

[12] Spinelli, Ana Cláudia NF, Anderson S. Sant'Ana, Cristiana P. Pacheco-Sanchez, and Pilar R. Massaguer. "Influence of the hot-fill water-spray-cooling process after continuous pasteurization on the number of decimal reductions and on Alicyclobacillus acidoterrestris CRA 7152 growth in orange juice stored at 35 C." International journal of food microbiology 137, no. 2-3 (2010): 295-298.

https://doi.org/10.1016/j.ijfoodmicro.2009.11.003

[13] Marois, J.J., D.R. Fravel, W.J. Connick Jr., H.L. Walker, and P.C. Quimby Jr. Preparation of Pellets Containing Fungi for Control of Soilborne Diseases. US Patent US4818530A.

[14] Silva, F. V. M. "Inactivation of Byssochlamys nivea ascospores in strawberry puree by high pressure, power ultrasound and thermal processing." International journal of food microbiology 214 (2015): 129-136. https://doi.org/10.1016/j.ijfoodmicro.2015.07.031

[15] Katan, Talma. "Heat activation of dormant ascospores of Talaromyces flavus." Transactions of the British Mycological Society 84, no. 4 (1985): 748-750. https://doi.org/10.1016/S0007-1536(85)80137-6

[16] Kim, H. J., and F. V. M. Silva. "Modeling the inactivation of Neosartorya fischeri ascospores in apple juice by high pressure, power ultrasound and thermal processing." Food Control 59 (2016): 530-537. https://doi.org/10.1016/j.foodcont.2015.06.033

[17] Bigelow, W. D., and J. R. Esty. "The thermal death point in relation to time of typical thermophilic organisms." The Journal of Infectious Diseases (1920): 602-617. https://doi.org/10.1093/infdis/27.6.602

[18] SCOTT, VIRGINIA N., and DANE T. BERNARD. "Heat resistance of Talaromyces flavus and Neosartorya fischeri isolated from commercial fruit juices." Journal of food protection 50, no. 1 (1987): 18-20. https://doi.org/10.4315/0362-028X-50.1.18

[19] Coleman, W. H., P. Zhang, Y-Q. Li, and P. Setlow. "Mechanism of killing of spores of Bacillus cereus and Bacillus megaterium by wet heat." Letters in applied microbiology 50, no. 5 (2010): 507-514. https://doi.org/10.1111/i.1472-765X.2010.02827.x

[20] KING JR, A. DOUGLAS, and LINDA C. WHITEHAND. "Alteration of Talaromyces flavus heat resistance by growth conditions and heating medium composition." Journal of food science 55, no. 3 (1990): 830-832.

https://doi.org/10.1111/j.1365-2621.1990.tb05241.x

[21] Beuchat, L. R. "Thermal tolerance of Talaromyces flavus ascospores as affected by growth medium and temperature, age and sugar content in the inactivation medium." Transactions of the British Mycological Society 90, no. 3 (1988): 359-364.

https://doi.org/10.1016/S0007-1536(88)80143-8

[22] Ho, K-LG. "Validation and commercialization of dense phase carbon dioxide processing for orange juice." In Case Studies in Novel Food Processing Technologies, pp. 209-225. Woodhead Publishing, 2010.

https://doi.org/10.1533/9780857090713.2.209

[23] Silva, Filipa M., Paul Gibbs, Margarida C. Vieira, and Cristina LM Silva. "Thermal inactivation of Alicyclobacillus acidoterrestris spores under different temperature, soluble solids and $\mathrm{pH}$ conditions for the design of fruit processes." International Journal of Food Microbiology 51, no. 2-3 (1999): 95-103.

https://doi.org/10.1016/S0168-1605(99)00103-8 
[24] Souza, Poliana BA, Keilane F. Poltronieri, Verônica O. Alvarenga, Daniel Granato, Angie DD Rodriguez, Anderson S. Sant'Ana, and Wilmer EL Peña. "Modeling of Byssochamys nivea and Neosartorya fischeri inactivation in papaya and pineapple juices as a function of temperature and soluble solids content." LWT-Food Science and Technology 82 (2017): 90-95. https://doi.org/10.1016/i.lwt.2017.04.021

[25] Berni, Elettra, Roberta Tranquillini, Nicoletta Scaramuzza, Andrea Brutti, and Valentina Bernini. "Aspergilli with Neosartorya-type ascospores: heat resistance and effect of sugar concentration on growth and spoilage incidence in berry products." International journal of food microbiology 258 (2017): 81-88. https://doi.org/10.1016/j.ijfoodmicro.2017.07.008

[26] Dijksterhuis, J., and P. G. M. Teunissen. "Dormant ascospores of Talaromyces macrosporus are activated to germinate after treatment with ultra high pressure." Journal of applied microbiology 96, no. 1 (2004): 162-169. https://doi.org/10.1046/i.1365-2672.2003.02133.x

[27] NGUYEN, ANH LINH. "CONTRIBUTION OF INTRINSIC FACTORS TO HEAT RESISTANCE OF ASCOSPORES OF BYSSOCHLAMYS." PhD diss., The University of New South Wales Sydney, 2012.

[28] Silva, Filipa VM. "Resistance of Byssochlamys nivea and Neosartorya fischeri mould spores of different age to high pressure thermal processing and thermosonication." Journal of Food Engineering 201 (2017): 9-16.

https://doi.org/10.1016/i.jfoodeng.2017.01.007

[29] Chapman, B., E. Winley, A. S. W. Fong, A. D. Hocking, C. M. Stewart, and K. A. Buckle. "Ascospore inactivation and germination by high pressure processing is affected by ascospore age." Innovative food science \& emerging technologies 8, no. 4 (2007): 531-534. https://doi.org/10.1016/i.ifset.2007.04.011

[30] Wyatt, Timon T., M. Richard van Leeuwen, Elena A. Golovina, Folkert A. Hoekstra, Eric J. Kuenstner, Edward A. Palumbo, Nicole L. Snyder et al. "Functionality and prevalence of trehalose-based oligosaccharides as novel compatible solutes in ascospores of $\mathrm{N}$ eosartorya fischeri (A spergillus fischeri) and other fungi." Environmental Microbiology 17, no. 2 (2015): 395-411. https://doi.org/10.1111/1462-2920.12558

[31] Beuchat, L. R. "Extraordinary heat resistance of Talaromyces flavus and Neosartorya fischeri ascospores in fruit products." Journal of Food Science 51, no. 6 (1986): 1506-1510. https://doi.org/10.1111/j.1365-2621.1986.tb13846.x 